AJHSE Vol: 1 (2): 66-83, 2020

Article Ref. No.: AJHSE010207

Accepted Date: October 01, 2020

(C) 2020. CC License 4.0

www.ajhse.org

CrossMark

\& click for updates
African Journal of Health, Safety and Environment

An official publication of the

Applied Environmental Bioscience and Public Health Research Group

University of Benin, Benin City, Nigeria

Open Access | Bi-annual | Peer-reviewed | International

ISSN (Online): 2695-1819 | ISSN (Print): 2695-2386

\title{
ANTIBIOTIC RESISTANCE IN BACTERIAL PATHOGENS ISOLATED FROM CATTLE DUNG AND ITS CONTAMINATED SOIL
}

\author{
${ }^{* 1}$ Obuekwe, I. S. and ${ }^{2}$ Offodile C. K.
}

*1, 2 Department of Microbiology, Faculty of Life Sciences, University of Benin, Benin City, Edo State, Nigeria

*Corresponding Author Email: ifeyinwa.obuekwe@ uniben.edu *Phone: 08029419741

${ }^{2}$ Email: offchinonso@gmail.com ${ }^{2}$ Phone: 08064256594

\begin{abstract}

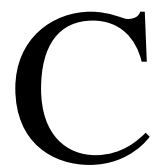
attle dung is used as organic fertilizer and alternative source of fuel or biogas but could also be a source of antibiotic resistance genes in the environment. This study isolated, identified and assessed antibiotic susceptibility pattern of bacteria from cattle dung and its contaminated soil. Bacteria isolation and identification were based on standard techniques while hemolytic activity was used to confirm potential pathogenic bacteria. Antibiotic susceptibility pattern of isolated pathogens were assayed by disk diffusion method. Among isolated bacteria, Staphylococcus spp had highest occurrence of $23.8 \%$ while Micrococcus spp was the least at $1.3 \%$. Hemolytic bacteria isolates were Staphylococcus aureus (16.5\%), Bacillus spp (17.4 \%), Nocardia spp (4.6 \%), Escherichia coli (29.4\%), Pseudomonas spp (13.8 \%), Serratia marcersens (2.8 \%) and Salmonella spp (15.6 \%). High resistance (100\%) against Ampiclox (30 $\mathrm{gg}$ ) was observed in all Staphylococcus aureus and Bacillus spp isolates while Pseudomonas aeruginosa isolates showed $100 \%$ resistance to Ofloxacin (30 $\mu \mathrm{g})$. Most Gram-positive bacterial isolates were majorly resistant to Beta lactams while Gram negative bacteria were resistant to Fluoroquinolones antibiotics. Multiple antibiotics resistant index (MARI) was measured at greater than 0.2, and was observed in 71.5 $\%$ of the hemolytic pathogens. Antibiotics resistance in hemolytic bacterial pathogens from this study is indicative of environmental sources of antibiotic resistance and possible adverse effects on human health.
\end{abstract}

Keywords: antibiotics, cattle dung, hemolytic bacteria, pathogens, resistance

LICENSE: This article by African Journal of Health, Safety and Environment (AJHSE)is licensed and published under the Creative Commons Attribution License 4.0 International License, which permits unrestricted use, distribution, and reproduction in any medium, provided this article is duly cited.

COPYRIGHT: The Author(s) completely retain the copyright of this published article.

OPEN ACCESS: The Author(s) approves that this article remains permanently online in the open access (OA) mode.

QA: This Article is published in line with "COPE (Committee on Publication Ethics) and PIE (Publication Integrity \& Ethics)". 


\section{INTRODUCTION}

Antibiotics have been used as panacea for the treatment of infections in both humans and animals for decades (WHO, 2014). They are often included in feed additives at small doses for growth promotion of animals used for meat, which account for large proportions of the global use of veterinary antibiotics (You and Silbergeld, 2014). The development of large-scale concentrated animal feeding operations (CAFOs) has increased the extensive use of veterinary antibiotics in the treatment of infections, prevention of diseases and promotion of growth (Sarmah et al., 2006; Jechalke et al., 2014; Van Boeckel et al., 2015).

Substantial proportions of the veterinary antibiotics administered are excreted in un-metabolized forms or as active metabolites in the soil (Sarmah et al., 2006). Evidence has shown that antibiotic residues can adversely affect microbial processes in the environment such as nutrient cycling and pollutants degradation (Sarmah et al., 2006; Jechalke et al., 2014). Similarly, antibiotics administered to animals provide selective advantages for antibiotic resistant bacteria (ARBs) to develop in animal intestines, which end up in their dung and eventually in the soil (Muurinen et al., 2017).

Animal manure could be a reservoir of bacteria carrying Antibiotic Resistant Genes (ARGs) and Mobile Genetic Elements (MGEs) such as plasmids (Feng-Hua et al., 2015; Yijun et al., 2018). When manure is used as fertilizer, residual antibiotics and ARGs could disperse into agricultural soils, which may exert selection pressure on antibiotic resistance (Martinez, 2009; Obuekwe and Osariemen, 2020). Antibiotic-resistance genes from the soil resistome can enter the food chain via contaminated crops or groundwater, and have potential consequences for human health if transferred to human pathogens (Marti et al., 2013; Nikolina et al., 2014; Adebisi et al., 2016). There is need to curb this problem by laying emphasis on improving productivity with less dependence on antibiotics especially for developing economics like Nigeria (Chollom et al., 2018). Again, strict control measures should be placed on antibiotics use through government policies and regulations, and where antibiotics are needed, there should be veterinarian prescription before use (Piddock et al., 2016; Chollom et al., 2018). This study assessed antibiotic susceptibility pattern of pathogens from cattle dung and its contaminated soil.

\section{MATERIAL AND METHODS}

\section{SAMPLES COLLECTION}

Fresh cattle dung, cattle dung manure and dung contaminated soils were collected in five (5) replicates from four (4) cattle settlement/market (Federal Staff road, Dumez junction, Upper Mission and Eyaen) within Benin City. Sterile plastic bags were used for fresh cattle dung and manure collection while cattle dung contaminated soils were collected using soil augers at a depth of 6 inches and then placed in a sterile plastic bag. Fifteen (15) samples of each category were collected for analysis, and the samples were collected during the rainy season in 2018. Methodology flowchart is shown in Figure 1. 


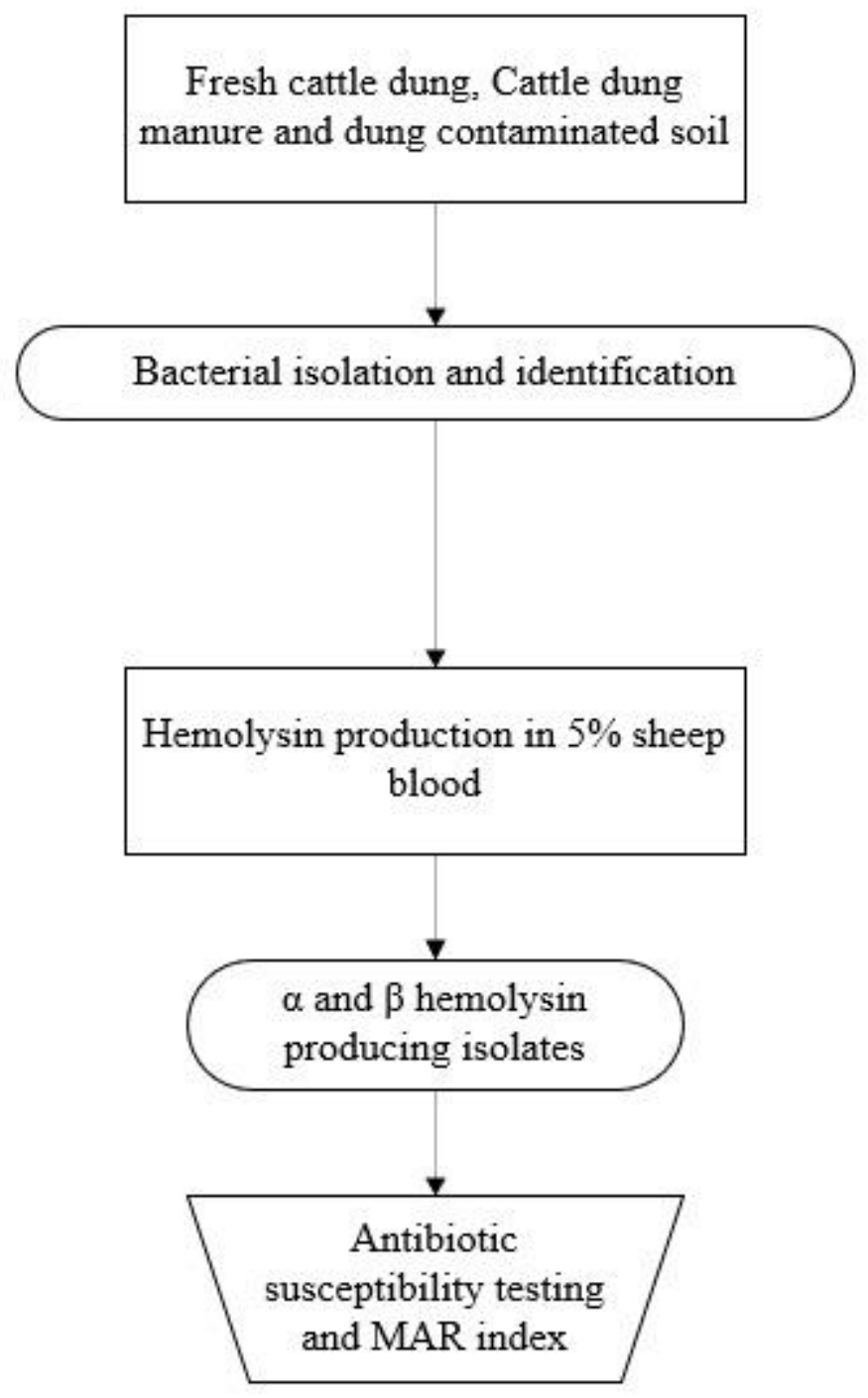

Figure 1: Methodology flowchart

\section{ISOLATION AND IDENTIFICATION OF BACTERIA}

The spread plate method was used for bacterial isolation. Ten- fold serial dilution of each sample was prepared aseptically in physiological saline up to $10^{-6}$ dilutions. Thereafter, $1 \mathrm{ml}$ aliquots of $10^{-5}$ and $10^{-6}$ dilutions were plated on nutrient agar (Himedia) and incubated at $37{ }^{\circ} \mathrm{C}$ for $24-48 \mathrm{~h}$ under aerobic conductions (APHA, 1999). Further identification was based on Gram's stain and biochemical tests (Cheesebrough, 2006) (Table 1).

\section{HEMOLYSIN PRODUCTION}

All bacterial isolates from samples were also cultured on $5 \%$ sheep blood agar (SBA) media as described by Pavlov et al. (2004) and Ryan et al. (2014). Plates were incubated at $37{ }^{\circ} \mathrm{C}$ for $24 \mathrm{~h}$ and growth was then observed for hemolytic activity of the bacteria. Greenish zone around the culture would indicate $\alpha$-hemolysis while clear transparent zone indicated $\beta$-hemolysis. 


\section{ANTIBIOTICS SUSCEPTIBILITY TESTING AND MULTIPLE ANTIBIOTICS RESISTANCE (MAR) INDEX OF BACTERIAL PATHOGENS}

Hemolysin producing isolates were sub-cultured on nutrient agar, and pure colonies of pathogenic bacteria were obtained. These were picked to make suspensions in $1 \mathrm{ml}$ sterile normal saline that was adjusted to an equivalence of a 0.5 McFarland standard. Subsequently, sterile Mueller-Hinton agar (Oxoid, UK; Bauer et al., 1966) plates were inoculated with them by spreading $0.1 \mathrm{ml}$ of each pathogenic bacterial suspension on the entire surface of the plate and then antibiotic discs were inserted. The following antibiotic sensitivity discs and concentrations were used for Gram positive; Ampiclox $(30 \mu \mathrm{g})$, Amoxicillin $(30 \mu \mathrm{g})$, Ceftriaxone $(25 \mu \mathrm{g})$, Cefuroxime $(20 \mu \mathrm{g})$, Perfloxacin $(10 \mu \mathrm{g})$, Ciprofloxacin $(10 \mu \mathrm{g})$, Gentymicin $(10 \mu \mathrm{g})$, Streptomycin $(30 \mu \mathrm{g})$, co-trimoxazole $(30 \mu \mathrm{g})$, Erythromycin $(10 \mu \mathrm{g})$. While gram negative disc used contained; Augmentin $(25 \mu \mathrm{g})$, Amoxicillin $(30 \mu \mathrm{g})$, Perfloxacin $(10 \mu \mathrm{g})$, Ofloxacin (30 $\mu \mathrm{g})$, Sparfloxacin $(10 \mu \mathrm{g})$, Ciprofloxacin $(10 \mu \mathrm{g})$, Gentamycin $(10 \mu \mathrm{g})$, Streptomycin (30 $\mu \mathrm{g})$, co-trimoxazole (30 $\mu \mathrm{g})$ and Chloramphenicol $(10 \mu \mathrm{g})$. Inoculated plates were allowed to air-dry within 15 minutes and then incubated at

$37^{\circ} \mathrm{C}$ for $24 \mathrm{~h}$. The zones of growth inhibition were measured and interpreted according to recommended standard (CLSI, 2017).

The multiple antibiotic resistance MAR index was determined for each bacterial pathogen by dividing the number of antibiotics the pathogenic bacteria was resistant to by the total number of antibiotics tested (Adenaike $e t$ al., 2016).

\section{RESULTS}

A total of sixty (60) samples of fresh cattle dung, manure and dung contaminated soils collected from four settlements within Benin City were microbiologically assessed. Out of these samples, one hundred and fifty-one (151) bacteria were recovered and were identified as Staphylococcus spp., Staphylococcus aureus, Micrococcus spp, Bacillus spp., Nocardia spp, Escherichia coli, Neisseria spp., Pseudomonas spp, Serretia marcescens and Salmonella spp (Table 1). 
Table 1: Cultural, morphological and biochemical characteristics of bacterial isolates

\begin{tabular}{|c|c|c|c|c|c|c|c|c|c|c|}
\hline Characteristics & B1 & B2 & B3 & B4 & B5 & B6 & B7 & B8 & B9 & B10 \\
\hline Shape & Irregular & Circular & Irregular & Circular & Circular & Circular & Irregular & Circular & Circular & circular \\
\hline Colour & Creamy & Creamy & Yellow & Yellow & Whitish & Creamy & Creamy & Creamy & Red & Creamy \\
\hline Margin & Rhizoid & Entire & Entire & Entire & Entire & Entire & Lobate & Rhizoid & Entire & Rhizoid \\
\hline Opacity & Opaque & Opaque & Opaque & Opaque & Opaque & Opaque & Opaque & Opaque & Opaque & Opaque \\
\hline Elevation & Raised & Raised & Raised & Raised & Raised & Raised & Raised & Raised & Raised & Raised \\
\hline Wet/ Dry & Wet & Wet & Wet & Wet & Dry & Dry & Wet & Wet & Dry & Dry \\
\hline Gram Stain & Positive & Positive & Positive & Positive & Positive & Negative & Negative & Negative & Negative & Negative \\
\hline Shape & Cocci & Cocci & Cocci & Rod & Rod & Rod & Cocci & Rod & Rod & Rod \\
\hline Arrangement & Clustered & Cluster & Pairs & Single & Pairs & Pairs & Single & Single & Single & Pairs \\
\hline Catalase & Positive & Positive & Positive & Positive & Positive & Positive & Positive & Positive & Positive & Positive \\
\hline Oxidase & Negative & Negative & Positive & Negative & Negative & Negative & Positive & Positive & Negative & Negative \\
\hline Coagulase & Negative & Positive & Negative & Negative & Negative & Negative & Negative & Negative & Negative & Negative \\
\hline Spore & Negative & Negative & Negative & Positive & Negative & Negative & Negative & Negative & Negative & Negative \\
\hline Motility & Positive & Positive & Negative & Positive & Negative & Negative & Negative & Positive & Positive & Negative \\
\hline Indole & Negative & Negative & Negative & Negative & Negative & Negative & Negative & Negative & Negative & Negative \\
\hline Urease & Negative & Negative & Negative & Negative & Negative & Negative & Negative & Negative & Positive & Negative \\
\hline Citrate & Positive & Negative & Negative & Positive & Negative & Positive & Negative & Positive & Positive & Positive \\
\hline Glucose & Negative & Positive & Positive & Negative & Negative & Positive & Negative & Negative & Positive & Negative \\
\hline Sucrose & Negative & Positive & Negative & Positive & Positive & Negative & Positive & Positive & Positive & Negative \\
\hline Lactose & Negative & Positive & Positive & Negative & Negative & Positive & Negative & Negative & Negative & Negative \\
\hline $\begin{array}{l}\text { Maltose } \\
\text { Isolates }\end{array}$ & $\begin{array}{l}\text { Positive } \\
\text { Staphylococcus } \\
\text { spp. }\end{array}$ & $\begin{array}{l}\text { Negative } \\
\text { Staphylococcus } \\
\text { aureus }\end{array}$ & $\begin{array}{l}\text { Negative } \\
\text { Micrococcus } \\
\text { spp }\end{array}$ & $\begin{array}{l}\text { Positive } \\
\text { Bacillus } \\
\text { spp. }\end{array}$ & $\begin{array}{l}\text { Negative } \\
\text { Nocardiaspp }\end{array}$ & $\begin{array}{l}\text { Positive } \\
\text { E.coli }\end{array}$ & $\begin{array}{l}\text { Negative } \\
\text { Neisseria } \\
\text { spp. }\end{array}$ & $\begin{array}{l}\text { Negative } \\
\text { Pseudomonas } \\
\text { spp }\end{array}$ & $\begin{array}{l}\text { Positive } \\
\text { Serretiamarcescens }\end{array}$ & $\begin{array}{l}\text { Positive } \\
\text { Salmonella } \\
\text { spp }\end{array}$ \\
\hline
\end{tabular}

However, Micrococcus spp, Nocardia spp, Neisseria spp and Serretia marcescens were absent in both fresh cattle dung and cattle dung manure samples but present in dung contaminated soil (Table 2). 
Table 2: Frequency of occurrence of bacterial isolates from fresh cattle dung, cattle dung manure and cattle dung contaminated soil samples

\begin{tabular}{lcllll}
\hline & & & & & \\
Bacterial Isolates & Dung $(20)$ & Manure $(20)$ & Soil $(20)$ & Total (60) & \% occurrence \\
\hline & & & & & \\
Staphylococcus spp & $14(70 \%)$ & $12(60 \%)$ & $10(50 \%)$ & $36(60 \%)$ & $36(23.8 \%)$ \\
Staphylococcus aureus & $8(40 \%)$ & $7(35 \%)$ & $3(15 \%)$ & $18(30 \%)$ & $18(11.9 \%)$ \\
Micrococcus spp & 0 & 0 & $2(10 \%)$ & $2(3.3 \%)$ & $2(1.3 \%)$ \\
Bacillus spp & $9(45 \%)$ & $7(35 \%)$ & $3(15 \%)$ & $19(31.67 \%)$ & $19(12.6 \%)$ \\
Nocardiaspp & 0 & 0 & $5(25 \%)$ & $5(8.33 \%)$ & $5(3.3 \%)$ \\
E.coli & $14(70 \%)$ & $9(45 \%)$ & $9(45 \%)$ & $32(53.33 \%)$ & $32(21.2 \%)$ \\
Neisseria spp & 0 & 0 & $4(20 \%)$ & $4(6.67 \%)$ & $4(2.6 \%)$ \\
Pseudomonas spp & $5(25 \%)$ & $5(25 \%)$ & $5(25 \%)$ & $15(25 \%)$ & $15(9.9 \%)$ \\
Serretia marcescens & 0 & 0 & $3(15 \%)$ & $3(5 \%)$ & $3(1.9 \%)$ \\
Salmonella spp & $8(40 \%)$ & $5(25 \%)$ & $4(20 \%)$ & $17(28.33 \%)$ & $17(11.3 \%)$ \\
Total number of isolates & $\mathbf{5 8}$ & $\mathbf{4 5}$ & $\mathbf{4 8}$ & $\mathbf{1 5 1}$ & $\mathbf{1 5 1}(\mathbf{1 0 0} \%)$ \\
\hline
\end{tabular}

In all 151 bacterial samples, Staphylococcus spp had the highest percentage occurrence of $23.8 \%$, followed by $E$. coli $(21.2 \%)$ and Bacillus spp (12.6\%) while Micrococcus spp and Serretia marcescens were the least bacterial isolates with percentage occurrence of $1.3 \%$ and $1.9 \%$ respectively (Table 2). These isolates were further tested for virulence factor using hemolysin production and it was observed that a total number of 109 isolates from each sample were pathogenic. Bacillus spp, Pseudomonas spp, Staphylococcus aureus, Salmonella spp, Nocardia spp, E. coli and Serretia marcescens were $\alpha$ and $\beta$ hemolysin positive. However, no hemolysin production was observed with Staphylococcus spp, Micrococcus spp and Neisseria spp (Table 3). 
Table 3: Frequency of distribution of hemolytic pathogens from fresh cattle dung, cattle dung manure and cattle dung contaminated soil samples

\begin{tabular}{|c|c|c|c|c|c|c|}
\hline \multirow[b]{2}{*}{ Bacterial Isolates } & \multicolumn{2}{|c|}{ Fresh Cattle dung } & \multicolumn{2}{|c|}{ Cattle dung manure } & \multicolumn{2}{|c|}{$\begin{array}{c}\text { Callte dung } \\
\text { contaminated soil }\end{array}$} \\
\hline & $\mathrm{N}$ & heamolysis +ve & $\mathrm{N}$ & heamolysis +ve & $\mathrm{N}$ & heamolysis $+v e$ \\
\hline Staphylococcus spp & 14 & 0 & 12 & 0 & 10 & 0 \\
\hline Staphylococcus aureus & 8 & $8(100 \%)$ & 7 & $7(100 \%)$ & 3 & $3(100 \%)$ \\
\hline Micrococcus spp & 0 & 0 & 0 & 0 & 2 & $0(0 \%)$ \\
\hline Bacillus spp & 9 & $9(100 \%)$ & 7 & $7(100 \%)$ & 3 & $3(100 \%)$ \\
\hline Nocardiaspp & 0 & 0 & 0 & 0 & 5 & $5(100 \%)$ \\
\hline E.coli & 14 & $14(100 \%)$ & 9 & $9(100 \%)$ & 9 & $9(100 \%)$ \\
\hline Neisseria spp & 0 & 0 & 0 & 0 & 4 & $0(0 \%)$ \\
\hline Pseudomonas spp & 5 & $5(100 \%)$ & 5 & $5(100 \%)$ & 5 & $5(100 \%)$ \\
\hline Serretiamarcescens & 0 & 0 & 0 & 0 & 3 & $3(100 \%)$ \\
\hline Salmonella spp & 8 & $8(100 \%)$ & 5 & $5(100 \%)$ & 4 & $4(100 \%)$ \\
\hline Total number of isolates & 58 & $44(75.9 \%)$ & 45 & $33(73.3 \%)$ & 48 & $32(66.7 \%)$ \\
\hline
\end{tabular}

Total number of isolates from each sample that are pathogenic $=109$

Legend: N/\%: Total number of bacteria/ percentages of occurrence; hemolysin +ve: percentage number of bacterial positive for hemolysin production.

Isolated hemolytic bacterial pathogens were subsequently subjected to common antibiotics to assess their resistance patterns as well as their percentage multiple antibiotic resistance indices (Table 4). 
Table 4: Percentage Multiple Antibiotics Resistance indices (MARI) > 0.2 Patterns of pathogenic bacterial isolates from fresh cattle dung, cattle dung manure and cattle dung contaminated soil samples

\begin{tabular}{|c|c|c|c|c|c|c|c|}
\hline \multirow{2}{*}{$\begin{array}{c}\text { Pathogenic bacterial } \\
\text { isolates }\end{array}$} & \multicolumn{2}{|c|}{ Fresh cattle dung } & \multicolumn{2}{|c|}{ Cattle dung manure } & \multicolumn{2}{|c|}{ Cattle dung contaminated soil } & \multirow[b]{2}{*}{ Total \% } \\
\hline & $\begin{array}{c}\text { Number of } \\
\text { isolates }\end{array}$ & MARI > 0.2 & $\begin{array}{c}\text { Number of } \\
\text { isolates }\end{array}$ & MARI > 0.2 & $\begin{array}{c}\text { Number of } \\
\text { isolates }\end{array}$ & MARI > 0.2 & \\
\hline Staphylococcus aureus & 8 & $7(87.5 \%)$ & 7 & $3(100 \%)$ & 3 & $3(100 \%)$ & $13(72.2 \%)$ \\
\hline Bacillusspp & 9 & $7(77.7 \%)$ & 7 & $7(100 \%)$ & 3 & $2(66.7 \%)$ & $16(84.2 \%)$ \\
\hline Nocardiaspp & 0 & & 0 & & 5 & 0 & 0 \\
\hline E. coli & 14 & $8(57.1 \%)$ & 9 & $7(77.8 \%)$ & 9 & $6(66.7 \%)$ & $21(65.6 \%)$ \\
\hline Pseudomonasspp & 5 & $5(100 \%)$ & 5 & $4(80 \%)$ & 5 & $3(60 \%)$ & $12(80 \%)$ \\
\hline Serretiamarcescens & 0 & & 0 & & 3 & 0 & 0 \\
\hline Salmonellaspp & 8 & $8(100 \%)$ & 5 & $4(80 \%)$ & 4 & $4(75 \%)$ & $16(94.1 \%)$ \\
\hline Total & 44 & $35(79.5 \%)$ & 33 & $25(75.8 \%)$ & 32 & $18(56.3 \%)$ & $78(71.5 \%)$ \\
\hline
\end{tabular}


The resistance profiles of isolated hemolytic pathogens are shown in Figures 2A, 2B, 3A, 3B, 4A and 4B.

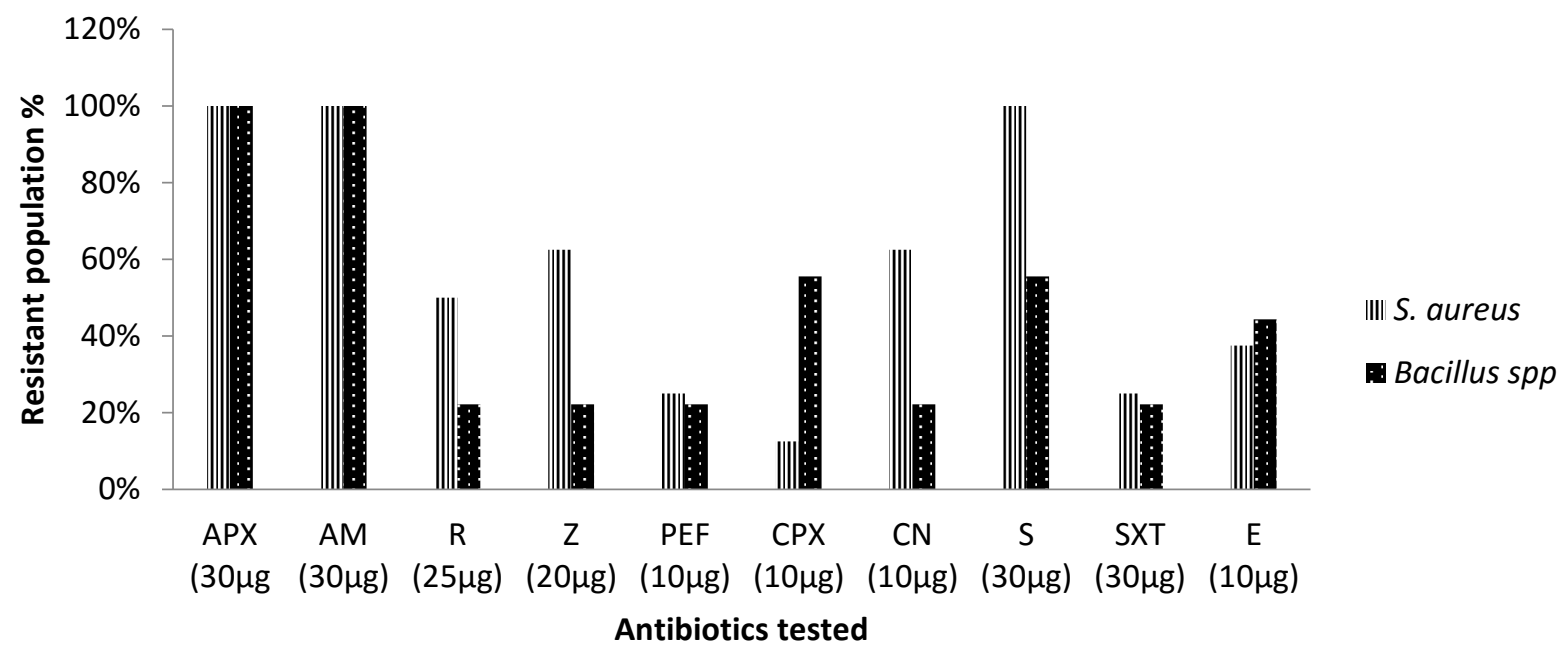

Figure 2A: Percentage number of antibiotics resistant Gram-positive bacteria isolated from fresh cattle dung in Benin City.

Legend: APX: Ampiclox; AM: Amoxicillin; CN: Gentamycin; S: Streptomycin; Z: Cefuroxime; R: Ceftriaxone; E: Erythromycin; SXT: Co-trimoxazole; PEF Perfloxacin; CPX: Ciprofloxacin

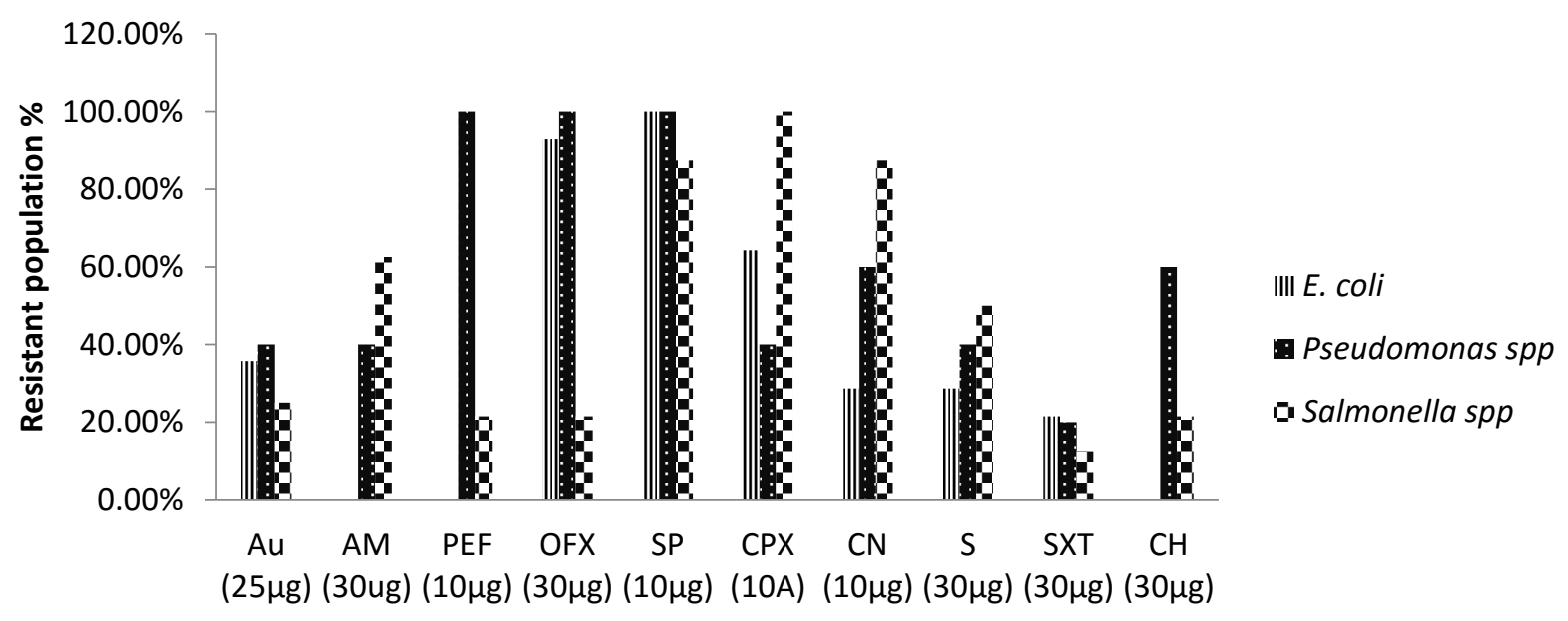

Antibiotics tested

Figure 2B: Percentage number of antibiotics resistant Gram-negative bacteria isolated from fresh cattle dung in Benin City.

Legend: AU: Augmentin; AM: Amoxacillin; CN: Gentamycin; S: Streptomycin; SXT: Co-trimoxazole; CH: Chloramphenicol; OFX: Ofloxacin; PEF Perfloxacin; SP: Sparfloxacin; CPX: Ciprofloxacin 


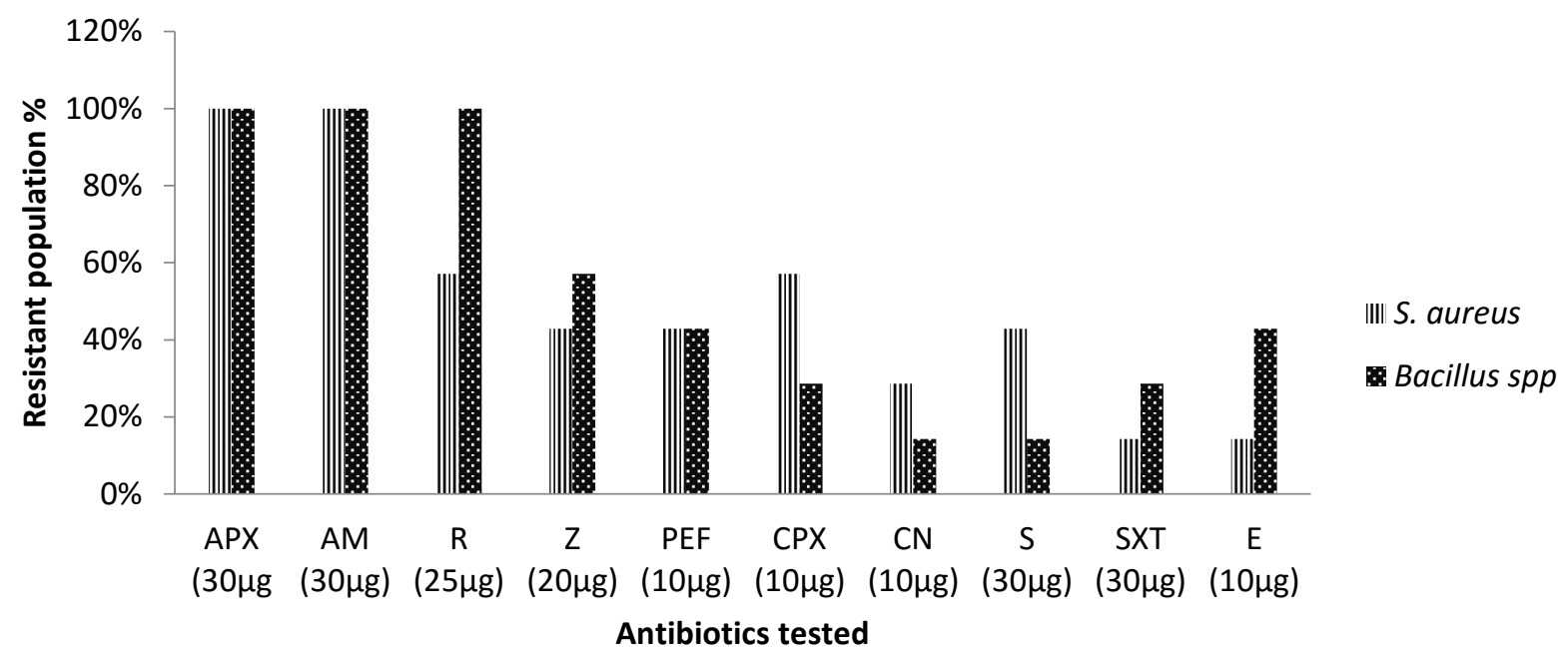

Figure 3A: Percentage number of antibiotics resistant Gram-positive bacteria isolated from cattle dung manure in Benin City.

Legend: APX: Ampiclox; AM: Amoxicillin; CN: Gentamycin; S: Streptomycin; Z: Cefuroxime; R: Ceftriaxone; E: Erythromycin; SXT: Co-trimoxazole; PEF Perfloxacin; CPX: Ciprofloxacin

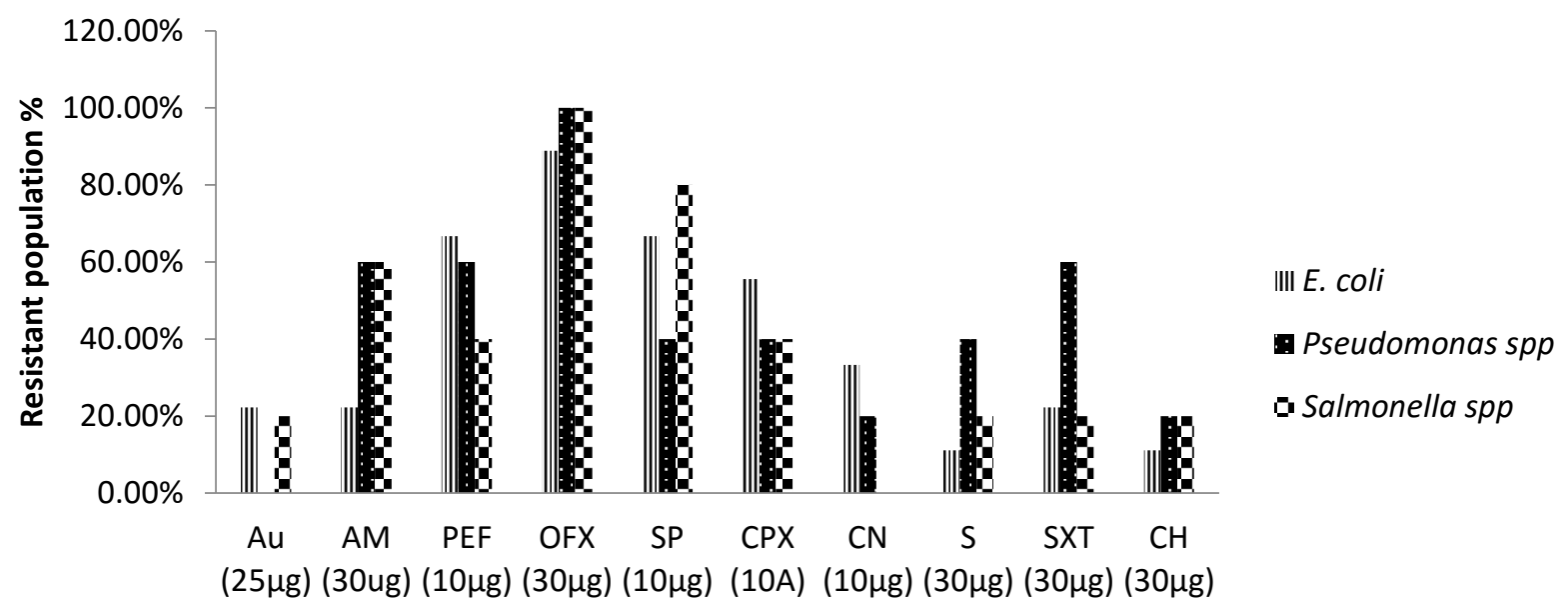

Antibiotics tested

Figure 3B: Percentage number of antibiotics resistant Gram-negative bacteria isolated from cattle dung manure in Benin City.

Legend: AU: Augmentin; AM: Amoxacillin; CN: Gentamycin; S: Streptomycin; SXT: Co-trimoxazole; CH: Chloramphenicol; OFX: Ofloxacin; PEF Perfloxacin; SP: Sparfloxacin; CPX: Ciprofloxacin 


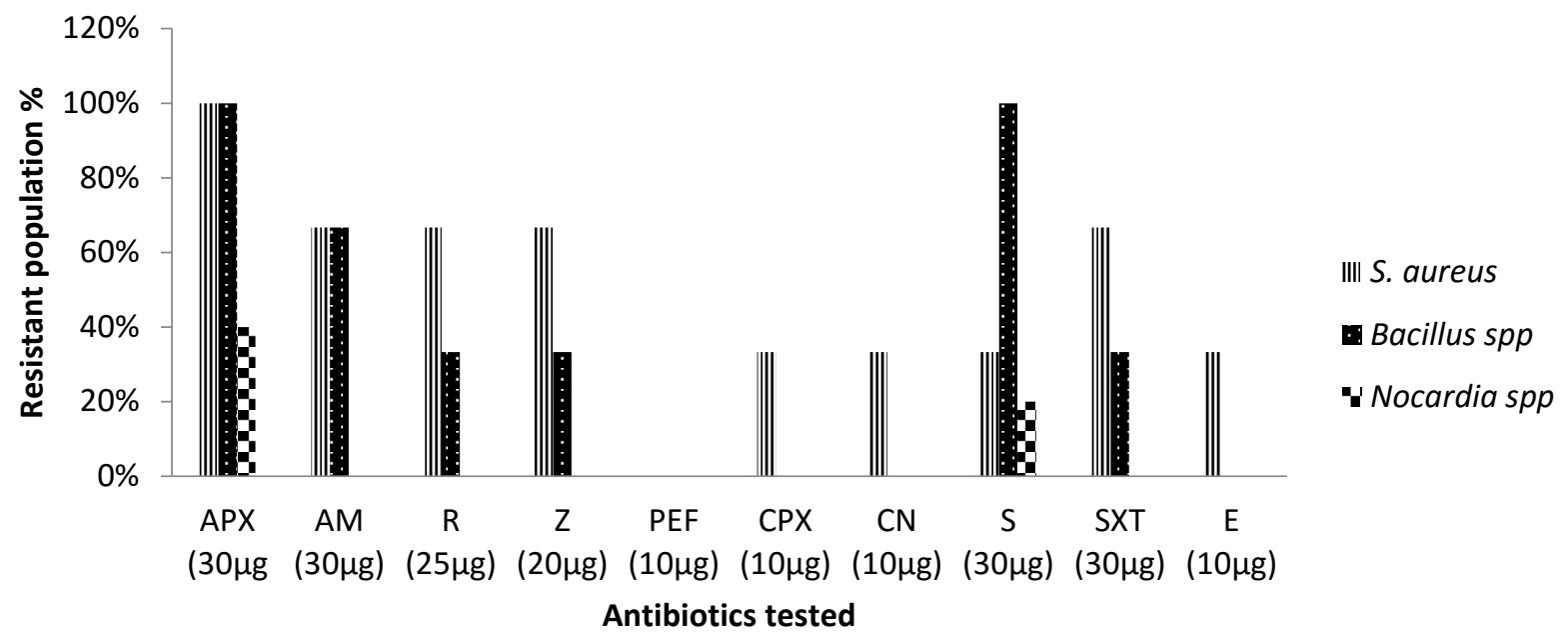

Figure 4A: Percentage number of antibiotics resistant Gram-positive bacteria isolated from cattle dung contaminated soil in Benin City.

Legend: APX: Ampiclox; AM: Amoxicillin; CN: Gentamycin; S: Streptomycin; Z: Cefuroxime; R: Ceftriaxone; E: Erythromycin; SXT: Co-trimoxazole; PEF Perfloxacin; CPX: Ciprofloxacin

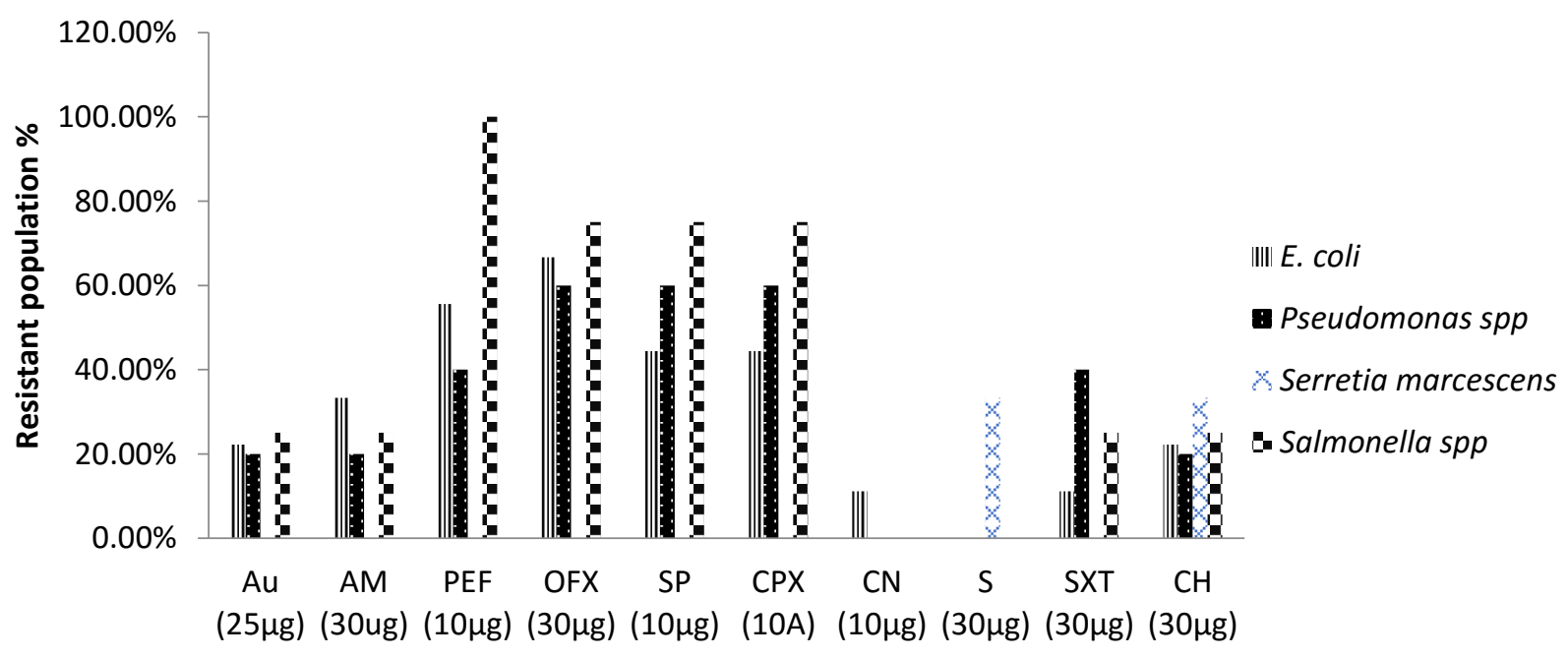

Antibiotics tested

Figure 4B: Percentage number of antibiotics resistant Gram-negative bacteria isolated from cattle dung contaminated soil in Benin City.

Legend: AU: Augmentin; AM: Amoxacillin; CN: Gentamycin; S: Streptomycin; SXT: Co-trimoxazole; CH:

Chloramphenicol; OFX: Ofloxacin; PEF Perfloxacin; SP: Sparfloxacin; CPX: Ciprofloxacin

Staphylococcus aureus isolated from fresh cattle dung showed $100 \%$ resistance to Ampiclox, Amoxicillin and Streptomycin but was least resistant to Ciprofloxacin (12.5\%). Similar pattern was also observed with Bacillus spp which showed $100 \%$ resistance to Ampiclox and Amoxicillin however, were least resistance to Ceftriaxone, 
Cefuroxime, Perfloxacin, Gentamycin and co-trimoxazole (22.2\%) (Figure 2A). Escherichia coli isolates from fresh cattle dung were resistant to both Sparfloxacin (100\%) and Ofloxacin (92.9\%) however, it was not resistant to Amoxicillin, Perfloxacin and Chloramphenicol (Figure 2B). On the contrary, Pseudomonas spp isolates were completely resistant to Ofloxacin, Perfloxacin and Sparfloxacin while been least resistant to Cotrimoxazole (20\%). Again, Salmonella spp isolates were highly resistant to Ciprofloxacin (100\%) followed by Sparfloxacin and Gentamycin (87.5\%) with least resistance to Cotrimoxazole (Figure 2B).

Staphylococcus aureus isolated from fresh cattle dung manure showed high resistance to Ampiclox and Amoxicillin (100\%) and least resistance to Erythromycin and Cotrimoxazole (14.3\%). Similar pattern was also observed with Bacillus spp which were resistant to Ampiclox, Amoxicillin and Ceftriaxone but not to Gentamycin and Streptomycin (14.3\%) (Figure 3A). The highest antibiotic resistance in E. coli isolates from cattle dung manure was observed with Ofloxacin $(88.9 \%)$ however, they were least resistant to Streptomycin and Chloramphenicol (11.1 $\%)$. Pseudomonas spp and Salmonella spp were highly resistant to Ofloxacin (100\%) but Pseudomonas spp was least resistant to Augmentin (0\%) while Salmonella spp was least resistant to Gentamycin (0 \%) (Figure 3B).

Staphylococcus aureus isolated from cattle dung contaminated soil showed highest resistance to Ampiclox $(100 \%)$ while the least resistance was observed with Perfloxacin (0 \%) (Figure 4A). Conversely, Bacillus spp isolates were resistant to both Ampiclox and Streptomycin (100\%) and not to Perfloxacin, Ciprofloxacin, Gentamycin and Erythromycin (0\%) (Figure 4A). Nocardia spp were also least resistant to Perfloxacin, Ciprofloxacin, Gentamycin and Erythromycin (Figure 4A). E. coli isolates however, showed highest resistance to Ofloxacin (66.7\%) with least resistance to Cotrimoxazole ( $0 \%)$. Similarly, Pseudomonas spp isolates showed highest resistant to Ofloxacin as well as sparfloxacin and Ciprofloxacin (60\%) while Salmonella spp were highly resistant to Perfloxacin (Figure 4B). Serretia marcescens isolated from cattle dung contaminated soil showed low level of resistance to Augmentin, Amoxicillin, Perfloxacin, Ofloxacin, Sparfloxacin, Ciprofloxacin, Gentamycin and Cotrimoxazole (0 \%) (Figure 4B). Amongst the three (3) categories of samples analyzed, fresh cattle dung contained the highest population of antibiotic resistant pathogens, followed by cattle dung manure, then cattle dung contaminated soil.

Multiple antibiotics resistance indices (MARI) of the hemolytic bacterial pathogens from all samples showed that highest percentage multi drug resistant population was observed in Salmonella spp (94.1\%). This was followed by Bacillus spp (84.2\%), Pseudomonas spp (80\%), Staphylococcus aureus (72.2\%) and E. coli (65.6\%). However, Nocardia spp and Serretia marcescens had no multi drug resistant population (Table 4).

\section{DISCUSSION}

Several bacteria (151) were isolated from cattle dung, manure and dung contaminated soil from cattle settlements in Benin City. Staphylococcus aureus, Bacillus spp, Escherichia coli, Pseudomonas spp, and Salmonella spp were isolated from all samples while Micrococcus spp, Nocardia spp, Neisseria spp and Serratia marcersens were only exclusive to cattle dung contaminated soil. Cattle dung is composed of about $80 \%$ water and supports a matrix of undigested plant material that is rich in nutrients, microorganisms and their byproducts (Muhammad and Amusa, 2003). Similar bacterial isolates (Staphylococcus aureus, Bacillus spp, Pseudomonas aeruginosa, Escherichia coli and Salmonella spp) were isolated from cattle dung in Kampar, Malaysia, and Ekiti state, Nigeria (Teo and Teoh, 
2011; Igbalajobi et al., 2015). Again, the lower parts of the gut of cattle contain various microorganisms including Enterococcus spp, B. subtilis, and Lactobacillus spp (Manyi-Loh et al., 2016). Conversely, the presence of Micrococcus spp, Nocardia spp, Neisseria spp and Serratia marcersens in dung polluted soil could be from other environmental sources. This could be heightened because of ecological disturbances such as flooding that lead to climate change (Mbah et al., 2016).

In this study Staphylococcus spp had the highest percentage occurrence of $23.8 \%$ which may be associated with mastitis (Roberts et al., 2018). This was followed by E. coli (21.2\%) and Bacillus spp (12.6\%) while Micrococcus spp and Serretia marcescens were the least bacterial isolates with percentage occurrence of $1.3 \%$ and $1.9 \%$ respectively. This result is similar with the studies of Manyi-Loh et al. (2016) who reported high isolation rates of S. aureus from cattle manure in relation to other isolated bacteria. Similarly, Spiehs and Goyal (2007) demonstrated that $S$. aureus was the second most numerous species isolated from cattle dung manure. Freshly laid cattle dung and stored domestic cattle dung contain consortia of microorganisms which include S aureus, Bacillus spp and E.coli (Teo and Teoh, 2011; Manyi-Loh et al. 2016). S. aureus, E.coli and other spp are important pathogens in human and veterinary medicine because of their ability to form enterotoxins and cause various diseases (Adebisi et al., 2016; Obuekwe and Osariemen, 2020).

Virulence factor based on hemolysin production by these isolates (Bacillus spp, Pseudomonas spp, Staphylococcus aureus, Salmonella spp, Nocardia spp, E. coli and Serretia marcescens) grouped them as pathogenic. Hemolysin is a bacterial protein that breaks down the membrane of red blood cells causing the release of hemoglobin. It acts by integrating into the membrane of the red blood cell and either punching a hole through the membrane or disrupting the structure of the membrane in some other ways (Verdon et al, 2009). One hundred and nine (109) out of these bacterial pathogens were positive for $\alpha$-hemolytic and $\beta$-hemolytic production which is an important virulence determinant of a disease outcome, and pathogenicity of commonly recognized pathogens such as Shiga-toxin producing E. coli, Salmonella, and Staphylococcus aureus (Spiehs and Goyal, 2007; Divyakolu et al., 2019; Obuekwe and Osariemen, 2020). E.coli is naturally found in the intestinal tract of animals, and shed with faeces however, Pathogenic hemolytic E. coli is known to cause many enteric diseases such as traveler's diarrhea and other forms of diarrhea (Carbone et al 2002; Adebisi et al., 2016).

Presence of high level of resistance to the tested antibiotics was observed in this study. S.aureus and Bacillus spp isolated from all three samples were $100 \%$ resistant to Ampiclox. However, only those isolated from fresh cattle dung and cattle dung manure were $100 \%$ resistant to Amoxicillin. Conversely, E. coli and P. aeruginosa isolates from fresh cattle dung and manure showed high resistance to Ofloxacin while this was observed in Salmonella spp from dung manure. This showed that majority of Gram-positive isolated bacteria were resistant to Beta lactams antibiotic while that of Gram negative were more resistant to Fluoroquinolones antibiotics. Studies have shown that Escherichia coli and Pseudomonas aeruginosa are sources of resistance genes for strains isolated from cattle dung despite the fact that they inhabit different ecosystems (Qingxiang et al., 2013). Resistance gene profiles are believed to play a very important role in mediating and transferring resistance to antibacterial drugs in the bacteria population. They can be localized in discrete transposable elements of DNA called transposons, which are mobile, and can move from one DNA molecule to another (Yijun et al., 2018). This can lead to the rapid spread of antibiotic resistance in a bacteria 
population, and explains the emergence of multi-resistant strains (Nain et al., 2015). Bacteria use three main strategies to get protected against $\beta$-lactams: alteration in Penicillin Binding Proteins (PBPs) which reduces the affinity of $\beta$ lactams, efflux pumps which remove the antibiotic from the bacterial periplasmic space, and production of $\beta$ lactamases which hydrolyze the ring of $\beta$-lactams (Zapun et al., 2008; Bush, 2013). However, resistance to quinolones has been a problem ever since Nalidixic acid was introduced into clinical medicine more than 40 years ago (Vranakis et al., 2013).

Generally, three mechanisms of resistance to quinolones are currently recognized: mutations that alter the drug targets, mutations that reduce drug accumulation and plasmids that protect cells from the lethal effects of quinolones (Hooper and Jacoby, 2015). Bacteria such as B. cereus, E. coli, Pseudomonas aeruginosa and Staphylococcus aureus isolated from cattle dung were reported to be resistant to several antibiotics including Penicillin, Amoxicillin, Ofloxacin, Pefloxacin, Ciprofloxacin, and Tetracycline (Bharti and Maneesha, 2015). Similar resistant pattern was also reported by Owojowo and Omojasola. (2013) in Escherichia coli, Aeromona hydrophila, Salmonella typhi, Staphylococcus aureus and Shigella dysenteriae from cattle dung with isolates showing high resistance to ampicillin, amoxicillin, gentamicin chloramphenicol and erythromycin. Utilization of antibiotics for other purposes other than therapy can enrich the population of resistant bacteria in the environment capable of infecting humans (Jose Luis Martinez., 2009). Nonetheless, low resistances to tested antibiotics were seen in Norcadia spp and Serratia marcersens which were exclusively isolated from cattle dung contaminated soil as well as Some E. coli isolates that were also susceptible to chloramphenicol. This is in agreement with Barbara et al. (2006) who reported antibiotics susceptibility of Nocardia spp. Comparably, Abu and Wondikom, (2018) reported the sensitivity of bacterial isolates to similar antibiotics such as Ciprofloxacin and Ofloxacin and opined their value as empiric antibiotic therapy for enteric infections. It has been shown that resistance to ciprofloxacin is usually associated with resistance to other macrolides, lincosamides, and type B streptogramin, and is referred to as MLS resistance (Ndirika et al., 2016).

Multiple drug resistance was seen in pathogenic Staphylococcus aureus, Bacillus spp, Escherichia coli, Pseudomonas aeruginosa and Salmonella spp in this study. This may be attributed to the presence of resistance determinants on plasmids with similar selective markers or as a result of independent, simultaneous development of resistance to different agents (Abu and Wondikom, 2018). These suggest that bacteria have the unique characteristics of being able to transfer resistance genes from one bacterium to another in different population and habitats (Mandal et al., 2011). Multiple antibiotic drug resistance profiles have also been reported in enteric bacteria from both human and animal sources (Ikpeme et al., 2011). Persistent multiple drug resistance of most isolates to appropriate drugs of choice are of great public health concern and calls for periodic monitoring of antibiograms to detect possible changing patterns (Davies, 2014). 


\section{CONCLUSION}

This study has shown that cattle dung, manure and dung contaminated soil may harbor resistant bacteria pathogens that may pose public health hazard. Cattle dung which is often used as organic manure can be a source of antibiotic resistance pathogenic bacteria in the soil environment. Cattle dung released in the environment should be monitored by farmers as well as national statutory agencies, and awareness programs created to enlighten the public and farmers regarding the safe use and handling of cattle dung. This could be possible through national statutory agencies such as National Environmental Standards and Regulations Enforcement Agency (NESRA). These activities will help prevent dissemination of pathogens in the environment and the transfer of infections to animals and human.

\section{REFRENCES}

Abu, G. O., and Wondikom, A. C. (2018). Isolation, Characterization and Antibiotic Resistance Profile Studies of Bacteria from an Excavated Pond in Port Harcourt Metropolis. Nigeria Journal of Applied Science and Environmental management, 22 (8) 1177-1184.

Adebisi, O. O., Olaoye, A. J., Senewo, T.V., and Obuekwe, I. S. (2016). How long can enteric pathogens survive in polluted Environmental media. Nigerian Society for Experimental Biology, 17 (3) 259-267

Adenaike, O., Olonitola, O.S., Ameh, J. B., and Whong, C. M. Z. (2016). Multidrug Resistance and Multiple Antibiotics Resistance Index of Escherichia coli strains Isolated from Retailed smoked Fish. Journal of Natural Science Research, 6(9): 7-10.

APHA, (1999). Standard Methods of Water and Wastewater Examination $18^{\text {th }}$ Edition. American Public Health Association, NY. Washintong DC. 2-172 pp.

Barbara, A. B., June, M. B., Patricia, S. C., and Richard, J. W. (2006). Clinical and laboratory features of the Nocardia spp. based on current molecular taxonomy. Clinical Microbiology Reviews, 19 (2), 259-282.

Bauer, A. W., Kirby, W. M., Sheris, J. C., and Turck, M. (1966).Antibiotic susceptibility testing by Standardized single disk method.American Journal of clinical Pathology, 45(4): 493-496.

Bharti, S., and Maneesha, S. (2015). Isolation and characterization of bacteria from cow dung of desi cow breed on different morpho-biochemical parameters in Dehradun, Uttarakhand, India. International Journal of Advances in Pharmacy, Biology and Chemistry, 4(2): 276-281.

Bush, K. (2013). Proliferation and significance of clinically relevant beta-lactamases. Annals of the New York Academy of Sciences; 1277 (1):84-90.

Carbone, S. R., Da Silva, F. M., Tavares, C. R. G., and Dias Filho, B. P. (2002). Bacterial population of a two-phase anaerobic digestion process treating effluent of cassava starch factory. Environmental Technology, 23(5), 591-597.

Cheesebrough, M. (2006). District laboratory Practice in Tropical Countries Part 2, $2^{\text {nd }}$ edition, Cambridge University 
Chollom, M. N., Rathilal, S., Swalaha, F. M., Bakare, B. F. (2018). Fate, transport, and toxicity of veterinary antimicrobials with an insight on Africa: A review. Ecology, Environment and Conservation. 24:1201-1220

Clinical Laboratory Standard Institute (CLSI) (2017). Performance Standards for Antimicrobial Susceptibility Testing (27th ed.). CLSI supplement M100S. Wayne, Pennsylvania 250 pp.

Davies, J. (2014). Inactivation of antibiotics and the dissemination of resistance genes. Science, 264: 375-382.

Divyakolu, S., Rosy Chikkala, R., Ratnakar, K.S., andSritharan, V. (2019). Hemolysins of Staphylococcus aureus An Update on Their Biology, Role in Pathogenesis and as Targets for Anti-Virulence Therapy. Advances in Infectious Diseases, 9: 80-104

Feng-Hua, W., Min, Q., Zheng, C., Jian-Qiang, S., and Yong-Guan, Z. (2015). Antibiotic resistance genes in manureamended soil and vegetables at harvest. Journal of Hazardous Materials, 299: 215-221.

Hooper, D. C., and Jacogy, G. A (2015). Mechanisms of drug resistance: Quinolone resistance. Annals of the New York Academy of Sciences doi: 10.1111/nyas.12830

Igbalajobi, O.A., David, O. M., Agidigbi, T.S. and Babalola, J.A. (2015). Antibiotic resistance pattern of two indicator bacteria isolated from cow dung across ten local government areas of Ekiti State. Nigeria. International Journal of Current Microbiology and Applied Science, 4(11): 8-14.

Ikpeme, E., Nfongeh, J., Enyi-Idoh, K., Eja, M. E., and Etim, L. (2011). Antibiotic susceptibility profiles of enteric bacterial isolates from dumpsite utisols and water sources in a rural community in cross river state, southern Nigeria. Nature and Science, 9(5):46-50.

Jechalke, S., Heuer, H., Siemens, J., and Smalla, K. (2014). Fate and effects of veterinary antibiotics in soil. Trends in Microbiology, 22:536-545.

Jose Luis, M. (2009). Environmental pollution by antibiotics and by antibiotic resistance determinants. Environmental Pollution, 157: 2893-2902.

Mandal, M.D., Mandal, S. and Pal, N.K. (2011). Antibiotic resistance prevalence and pattern in environmental bacterial isolates. The Open Antimicrobial Agents Journal, 3: 45-52.

Manyi-Loh, C. E., Sampson, N., Mamphweli, E. L., Makaka, G., and Michael, S. (2016). An overview of the control of bacterial pathogens in cattle manure. International Journal of Environmental Resource and Public Health, 13(9): 838-843.

Marti, R., Scott, A., Tien, Y.C., Murray, R., Sabourin, L., Zhang, Y.,and Topp, E. (2013). Impact of manure fertilization on the abundance of antibiotic-resistant bacteria and frequency of detection of antibiotic resistance genes in soil and on vegetables at harvest. Applied Environmental Microbiology, 79: 5701-5709.

Martinez, J. L. (2009) Environmental pollution by antibiotics and by antibiotic resistance determinants. Environmental Pollution, 157: 2893-2902. 
Mbah, E. I., Abu, G. O., and Ibe, S. N. (2016). Metagenomes- Based Investigation of the Impact of Natural Run-offs and Anthropogenesis on a Freshwater Ecosystem at Points of Use in Niger Delta, Nigeria. International Journal of Innovative Research Development, 5(3): 297-304.

Muhammad, S., and Amusa, N. A. (2003). In vitro inhibition of growth of some seedling blight inducing pathogens by compost inhibiting microbes. African journal biotechnology, 2 (6):161-164.

Muurinen, J., Stedtfeld, R., Karkman, A., Pärnänen, K., Tiedje, J. and Virta, M. (2017). Influence of Manure Application on the Environmental Resistome under Finnish Agricultural Practice with Restricted Antibiotic Use. Environmental Science and Technology, 51(11): 5989-5999.

Nain, V.K., Khurana, G.S., Singh, S., Vashitha, A. and Sangeeta, A. (2015). Antibiotic resistance pattern in bacterial isolates obtained from different water samples of Delhi Region. African Journal of Bacteriology Research, 9(1): $1-8$.

Ndirika, D., Nnabue, M. U., Amechi, S. N. and Chinwe, J. A. (2016). Pathogenic bacteria prevalence in a selected environmental sample and their sensitivity to routine antibiotics. International Journal of Current Microbiology and Applied Sciences, 5(8): 862-872

Nikolina, U., Fabienne, W., Nichole, A. B., and Jo H. (2014). Bloom of resident antibiotic-resistant bacteria in soil following manure fertilization. Proceedings of the National Academy of Sciences of the United States of America, 111:15502-15207.

Obuekwe, I. S., and Osariemen, P. O. (2020).Antibiotic Resistance in Hemolytic Bacterial pathogens from Hospital Wastewaters.Nigerian Journal of Microbiology, 34 (1): 4945-4953

Omojowo, F. S. and Omojasola, F. P. (2013). Antibiotic resistance pattern of bacterial pathogens isolated from cow dung used to fertilize Nigerian fish ponds. Natural Science Biology, 5(1):15-19.

Pavlov, D., De-Wet, C. M. E., Grabow, W. O. K. and Ehlers, M. M. (2004). Potentially pathogenic features of heterotrophic plate count bacteria isolated from treated and untreated drinking water. International Journal of Food Microbiology, 92: 275 - 287.

Piddock, L., Garneau-Tsodikova, S., Garner, C., 2016. Ask the experts: how to curb antibiotic resistance and plug the antibiotics gap? Future Medicinal Chemistry, 8: 1027 - 1032.

Qingxiang, Y., Siwei, R., Tianqi, N. and Yuhui, G. (2013). Distribution of antibiotic-resistant bacteria in chicken manure and manure-fertilized vegetables. Journal of Undergraduate Research and Innovation, 1(3): 219227.

Roberts, M. C., Garland-Lewis, G., Trufan, S., Meschke, S. J., Fowler, H., Shean, R. C., Alexander L Greninger, A. L., Rabinowitz, P. M (2018).. Distribution of Staphylococcus species in dairy cows, workers and shared farm environments. FEMS Microbiology Letters, 365 (15) fny146, https://doi.org/10.1093/femsle/fny146 
Ryan, K. J., Ray, C. G. and Sherris, J. C. (2004). Sherris Medical Microbiology: An introduction to infectious Disease. $4^{\text {th }}$ Edition, McGraw Hill, New York, U. S. A.979 p.

Sarmah, A.K., Meyer, M. T. and Boxall, A.B. (2006). A global perspective on the use, sales, exposure pathways, occurrence, fate and effects of veterinary antibiotics (VAs) in the environment, Chemosphere 65:725-759.

Spiehs, M. and Goyal, S. (2007). Best Management Practices for Pathogen Control in Manure Management Systems. University of Minnesota Extension, New York. 211pp.

Teo, K. C. and Teoh, S. M. (2011). Preliminary biological screening of microbes isolated from cow dung in Kampar. African Journal of Biotechnology, 10(9): 1640-1645.

Van Boeckel. P., Thomas, B. C., Gilbert, M., Grenfell, T. B., Levin, A. Simon., Robinson, P. T., Aude, T., and Ramanan, L.(2015). Global trends in antimicrobial use in food animals. Proceedings of the National Academy of Sciences of the United States of America, 112: 5649-5654.

Verdon, J., Girardin, N., Lacombe, C., Berjeaud, J and Hechard, Y. (2009). Delta-hemolysin, an update on a membrane-interacting peptide. Peptides, 30: 817-823.

Vranakis I., Goniotakis I., Psaroulaki A., Sandalakis V., Tselentis Y., Gevaert K., Tsiotis G. (2013). Proteome studies of bacterial antibiotic resistance mechanisms. Journal of Proteomics, 97:88-99.

World Health Organization. (2014). Antimicrobial resistance: global report on surveillance 2014. World Health Organization, Geneva. [accessed on 4 August 2016].

Yijun, K., Qing, L., Zhifeng, Y., Min, S., Haitao, Z., Yanchao, B., Lijuan, M., and Jian, H. (2018). High diversity and abundance ofcultivable tetracycline-resistant bacteria in soil following pig manure application. Scientific Report, 8: 1-13.

You, Y and Silbergeld, K. E. (2014). Learning from agriculture: understanding low-dose antimicrobials as drivers of resistome expansion. Frontiers in Microbiology, 5(284)1-10. Doi:10.3389/fmicb.2014.00284.

Zapun A, Contreras-Martel C, Vernet T. (2008). Penicillin-binding proteins and betalactam resistance. FEMS Microbiology Reviews, 32: 361-385. 